[Watson, S., Hughes, D., Lauder, H., Strathdee, R., \& Simiyu, I. (1998). Ethnicity and School Choice. New Zealand Annual Review of Education, 7, 95-110]

\section{Ethnicity and School Choice}

\author{
Sue Watson, David Hughes, Hugh Lauder, ROBERT \\ STRATHDEE AND IBRAHIM SIMIYU
}

\section{Abstract:}

The issue of school choice has been the focus of a growing amount of research and theoretical work in education policy. In this article, we focus on ethnicity in relation to school choice, since our research indicates that it is a key factor in understanding the evolving dynamics of the secondary education market in Aotearoa/New Zealand. By drawing on data collected by The Smithfield Project since 1992, we track the patterns of school "choice" of students and their families and the effects of selection exercised by some schools. We argue that many Maori and Pacific Islands students are disadvantaged by zoning policies aimed at increasing parental choice of school, and that the schools which serve these students have been hardest hit by the competitive mechanisms introduced into educational provision.

n 1992 the Smithfield Project began its research work, with the central aim of monitoring the impact of major policy changes in education introduced in the 1989 Education Act and extended in the 1991 Education Amendment Act. In brief, those policy changes were based on the belief that introducing competition into the provision of education would improve outcomes, because schools would be forced to compete for students and would therefore raise their educational standards in order to do so. A central mechanism for creating competition was to increase parental choice of school. School zones were removed so that students would, in theory, have the freedom to attend the school of their choice. This was a change from previous legislation which essentially required students to attend the school they were in zone for. McCulloch $(1990 ; 1991)$ has detailed the complex situation regarding zoning prior to the 1989 Education Act, but Chapman (1995, p. 8) has suggested that in essence the ability to choose schools within the state system was limited to "... those who could afford to move and
96 Sue Watson et al.

purchase a residence within the catchment area of their favoured school."

Because school choice was central to the creation of competition, a key aim of our research has been to learn about the processes of school choice under the new policies. Since we began our research we have collected a substantial amount of both quantitative and qualitative data about school choice. In this article, we focus on ethnicity in relation to school choice, since our research indicates that it is a key factor in understanding the evolving dynamics of the secondary education market in Aotearoa/New Zealand and it is an issue that has received little attention in the literature to date. It is our hope that this paper will act as a stimulus to further research work into this complex area.

\section{The Background}

The background to the changes to school zoning is now well documented, but it is worth re-stating here the key assumptions on which the removal of zoning was based. First, it was assumed that the removal of zoning would give individuals a greater choice as to the school they could attend. This assumption rested on the belief that the supply of desired schools would equal the demand and that all individuals would have an equal ability to access the school of their choice. Secondly, it was assumed that schools would compete for students by modifying their policies and practices if they were not successful in attracting sufficient numbers of students. Thirdly, it was assumed that this kind of competition would lead to an improvement in outcomes, particularly for those students who have been persistently disadvantaged by the system of state education provision in Aotearoa/New Zealand.

There are two ways in which the introduction of an education market was to address the failure of the education system for Maori and Pacific Islands students. Firstly, it would remove the "iron cage of zoning", which it was claimed was limiting the choice of these students by forcing them to remain in under-performing schools (Benton, 1987). Secondly, it was envisaged that as "consumers" they would have the power to influence school policy to be more responsive to their learning requirements, and this would ultimately encourage diversity of provision within the educational market. We begin by examining these assumptions in the light of our research findings.

In our third report to the Ministry of Education (Lauder et al., 1995) we presented an exploratory analysis of ethnic choice patterns which 
enabled us to examine two questions. Firstly, do Maori and Pacific Islands parents/whanau/aiga have different patterns of choice from their Pakeha counterparts, and are they equally able to access their preferred school? The data in that report were based on a written questionnaire completed by parents and caregivers in 1994 - the year that the students in our longitudinal cohort began secondary school. Because of the relatively low response rate from Maori and Pacific Islands families, follow-up phone interviews were made by Maori and Samoan interviewers. The following results are based on nearly 2,000 responses to the parents' questionnaires and follow-up phone interviews. Eight percent of the responses were from Maori families, five percent were from Pacific Islands parents, six percent were from those we have coded as "Other" (who were predominantly Asian), and the rest were European or Pakeha.

\section{The Notion of "Circuits"}

The first question we asked parents was, "Of the secondary schools available to you, which one did you most want your son/daughter to go to?" To analyse the responses, we introduced the notion of "circuits" as a method of dividing schools according to their popularity within the education market we studied (Ball, Bowe \& Gewirtz, 1995). High circuit schools all operated enrolment schemes, had a high mean SES and, with one exception, were single sex in character. These schools had relatively high numbers of students who travelled long distances to attend them. Low circuit schools often had declining student numbers, had a low mean SES and were all co-educational. Middle circuit schools had a mean SES between that of the high and low circuit schools, and while one or two operated enrolment schemes, they had relatively few students travelling long distances to attend them. They comprised both single sex and co-educational schools.

Highly significant differences were found between ethnic groups on this question, just as there were between socio-economic groups. Maori parents were the least likely to prefer high circuit schools (30 percent), while Pacific Island parents (41 percent) seemed just as likely as Pakeha parents (42 percent) to prefer high circuit schools. Those coded "Other" were most likely to prefer high circuit schools (61 percent). The Maori parents were almost evenly split between high, middle and low circuit schools, whereas the Pacific Islands parents were polarised with roughly the same percentages preferring low and high circuit schools, and only
19 percent opting for middle circuit schools. Pakeha parents (14 percent) and Other parents (11 percent) rarely preferred low circuit schools.

The next question related to which schools parents actually applied for. As was the case with relationships between SES and school choice, parents who state a preference for a school in a particular circuit, by and large apply for that circuit (Lauder et al., 1995). The applications to high circuit schools expressed as a percentage of those who prefer a high circuit school is never less than 87 percent for any ethnic group.

However, patterns of attendance reveal a different picture. The percentages of students attending a high circuit school were 16 percent, 33 percent, 38 percent and 46 percent for Maori, Pacific Island, Pakeha and Other families respectively. Those attending a high circuit school expressed as a percentage of those who preferred a high circuit school were 53 percent for Maori families, 75 percent for Other families, 80 percent for Pacific Island families and 90 percent for Pakeha families.

This immediately raises the question of why it might be that so few Maori students attend high circuit schools, even when they state a preference for these schools and apply to them. The most obvious conclusion is that these schools are in some way discriminating against Maori students in their selection criteria. It is worth reflecting on the fact that all of the high circuit schools in the market we studied were able to operate an enrolment scheme, since they had more applicants than places available. They are therefore able to exercise some control over their student intake.

In order to investigate the question of whether schools do indeed select on the basis of ethnicity, an analysis of covariance was run for those families which had applied to at least one high circuit school, using the mean Progressive Achievement Test (PAT) T-score and SES as covariates, and ethnicity as the independent variable. The probability of applications for high circuit schools being accepted by those schools was the dependent variable. The analysis showed that ethnicity is a factor $(\mathrm{p}=.002)$, over and above achievement and SES, in determining the ability of parents and students to realise their choices in the education market place.

The unequal rates of acceptance by ethnic group membership introduces the reality that in some cases it is the school which is doing the choosing and not just the student, and that some students, like some schools, are clearly perceived to be more desirable than others. The data indicate that the desirability of students is related to ethnicity (as well as to social class - although the two are inextricably linked in New 
Zealand) and it is also the case that the desirability of a school is related to ethnicity. The over-subscribed schools, and therefore the most desirable, in the markets studied, were also those with the lowest proportions of non-Pakeha students.

Although our data do not enable us to examine the reasons why parents choose particular schools, research by Wells (1995) suggests that the rationale for choices will differ within ethnic groups. Wells interviewed 37 African-American high school students and 34 of their parents and grandparents about their choice of school. She concluded:

And while both race and class affect students' habitus, and therefore the way they perceive school choice opportunities, not all low-income minority students and parents will react the same way. Some will actively seek out schools that they believe will help them to attain higher status; others who fear competition or failure in a high-status school and those who have lost faith in the educational system will be most likely to choose not to choose. (p. 33)

For groups which have been traditionally excluded from the benefits of the formal education system, such varied responses are not surprising, and indeed have also been identified in the literature with respect to working class students (Brown, 1987; Lauder et al., 1992). Clearly, choice within the context of a system that has been exclusionary is likely to be highly problematic for those who have been disadvantaged by it, and a uniform rational response in the terms predicted by the neo-classical economists is hardly to be expected.

However, the specific range of responses that excluded groups make will be determined by their history and culture. With this in mind, we re-visited the sub-sample of Maori and Pakeha parents in one urban centre who were interviewed in detail about their school choice in 1993 when their children were in Form 2. Thirty-six Maori parents and 204 Pakeha parents were interviewed.

While the numbers are small, one result that emerged was that 22 percent of Maori said they were considering sending their child to a church-related boarding school. Furthermore (in Pakeha terms) the majority of these were from lower SES backgrounds, although their status may be assessed quite differently within the Maori community. In contrast, less than two percent of Pakeha parents said they were considering boarding schools.

Our data suggest the possibility that these boarding schools, most of which are Maori in character, provide an important alternative to mainstream schooling for Maori families and are an indication of the desire by many Maori parents for an educational context which they believe is able to provide both academic achievement and a culturally appropriate environment. While many of these families had access to a local school which had a high percentage of Maori students and had been making an increasing effort to be bicultural, this school may not have been perceived as according to its students the same levels of achievement as a boarding school. These parents' assessments of the benefits of Maori boarding schools is consistent with those of Benton (1987), when he notes that: “... presence at a Maori boarding school was one of several factors isolated as having positive effects on achievement among secondary students in Waikato" (p. 45).

It is important to note, however, that the establishment of these schools pre-existed the current market context. At present there are no such alternatives available for the growing numbers of Pacific Islands students, and it is difficult to see how the current market context can stimulate such initiatives.

At the individual level then, we have been able to show that the ability to exercise choice of school is not distributed equally across all ethnic groups. Pakeha families are the most likely to be able to attend their preferred type of school. This is not simply a matter of socio-geography. Where the preferred school is able to operate an enrolment scheme and select students, those from Pakeha families are most likely to be selected, even after ability in the form of mean PAT T-scores and SES have been controlled for.

\section{The Composition Data}

As well as collecting data from the students and parents/caregivers in our cohort, we have also been collecting data on the Form 3 intakes of 11 secondary schools in one New Zealand city which we have named Green City. This has been termed the composition data, and it has enabled the tracking of the impact of the removal of zoning on the intake characteristics of these schools. Such data are available from 1990, the year prior to the removal of zoning, through to 1995.

This composition data set has enabled us to place the data from our cohort into a larger context and, importantly, to track the effect that individual actions with respect to school choice have on the shape of the education market. The relationship is not linear, however, and it is clear that the selection that is undertaken by schools affects the choices made by parents and students. 
The first analysis we undertook was to track the movements of students to or away from their local school. To do this, on an area by area basis, the different schools were categorised as being either local, adjacent or distant. Schools were considered local when students lived within the original (1990) zone boundaries of the school. Schools which were clearly not the local school and for which travel was required were considered adjacent. To get to distant schools, students bypassed their local school and at least one other in a way that involved considerable travel.

In 1990, higher percentages of Maori students (79 percent) and Pacific Island students (83 percent) attended local schools than either Pakeha students (74 percent) or Other students (76 percent). However, by 1995, a dramatic change had taken place with proportionally fewer Maori students (61 percent) and Pacific Island students (62 percent) now attending their local schools. Corresponding figures for Pakeha students were 67 percent, and for Other students 65 percent. This represents a drop of about 20 percent in Maori and Pacific Islands students attending their local school, compared with a drop of approximately half this amount for Pakeha and Other students. The percentages attending distant schools showed little change over the time covered by the study, but the percentages attending adjacent schools increased steadily.

At face value, these figures would seem to indicate that Maori and Pacific Island students are taking advantage of the new legislation to a greater degree than Pakeha and Other students. However, the situation is complex, and once the socio-economic background of the students and the socio-geography of different school catchments are considered in detail a more complete picture emerges.

We found that those who attended distant schools consistently came from higher SES homes than those who attended local or adjacent schools. However, with the exception of the year 1990, students attending adjacent schools came from the lowest mean SES homes.

It appears, then, that de-zoning has increased the number of lower SES students attending an adjacent school. However, these figures do not take into account the fact that students living close to schools with good reputations have no reason to bypass them and, of course, these schools tend to be in the higher socio-economic areas. As we showed in our first composition report (Lauder et al, 1994), the more pertinent issue to address is whether there are ethnic or SES differences "in the propensity to pursue enrolment options within the same attendance area" (Maddaus, 1990, p. 284). It is to this issue that we now turn.
Our data allow us to take neighbourhood characteristics into account to monitor trends both within and between suburbs. In order to focus on enrolment processes for a given residential area, each student's SES was compared to the mean SES of the neighbourhood the student lived in to give a measure we termed "relative SES". A positive "relative SES" indicates that the student is of higher SES than typical for the neighbourhood in which he or she lives; a negative "relative SES" indicates that the student is of lower SES than typical for the neighbourhood. When calculating relative SES, the mean SES of each neighbourhood was computed on a year-by-year basis to ensure the greatest possible accuracy.

Our analysis showed that the relative SES of students attending local schools was consistently lower than that of students attending adjacent or distant schools. This indicated that local schools were consistently populated by students whose families had lower SES than others in their neighbourhoods. In contrast, students who attended adjacent or distant schools were from families which had relatively high SES in comparison with their neighbourhoods. Therefore, in contrast to the picture presented when we looked only at the SES of individual students, once their neighbourhood SES was taken into account, it was the relatively well-off students who attended adjacent schools after 1991; those relatively worse off were most likely to go to their local school.

It appears, then, that dezoning has not increased the likelihood that students who are relatively worse-off (in comparison with their neighbourhood) will attend non-local schools. This finding is highly significant since it undermines the belief that those students who had traditionally been most disadvantaged by zoning would benefit most from its removal.

\section{"White Flight" and "Brown Flight"}

This movement away from some local colleges has given rise to a phenomenon which has become known as "white and brown flight". This refers to the movement of Pakeha and some Pacific Islands and Maori students away from their local working-class schools to adjacent or distant schools with higher proportions of Pakeha students. The reasons for this movement are the subject of conjecture, since it is very difficult to collect qualitative data about the reasons for school choice. In our experience, parents and students give a range of (apparently) contradictory reasons for their choices, which are not easily prioritised. This may be because school choice is a complex process, which has as 
much to do with such things as identity as it has to do with purely educational concerns. Gordon (1994), in an overview of research on school choice in Aotearoa/New Zealand, concluded that, "patterns of school choice ... are directly related to the class and ethnic character of the area in which schools are located" (p. 13).

It does seem that the ethnic and SES mix of the school is an important consideration for many parents in their choice of school. This is perhaps best illustrated by the experience of one of the schools in our study which we named Weka College. Weka College is uniquely positioned between a working class area with a high percentage of Maori and Pacific Island students and a white middle class area. In 1990, prior to the removal of zoning, just over half of the students in the school were Pakeha with almost a quarter being Maori and the same proportion coming from Pacific Island families. The school had a mean SES of 3.7 on the version of the Elley/Irving SES index used (where 1 indicated the highest SES and 7 the lowest). By 1995, while the actual numbers of students had changed very little, the composition of the intake clearly had. By 1995, Maori, Pacific Islands and Pakeha students each comprised approximately one third of the Form 3 intake, and the mean SES had dropped to 4.5. There were several reasons for this change in composition (Lauder et al., 1994). Firstly, there was a belief amongst many Pacific Island parents that their children would do better at schools with a greater proportion of Pakeha students. Secondly, as the non-Pakeha roll increased, Pakeha enrolments declined markedly. The principal of Weka College had little doubt that the white flight that followed the increased Maori and Pacific Island enrolments had both racial and socio-economic dimensions. According to the principal, racism played a part in this white flight, so that if he was to keep an ethnically well balanced school, "We need to be able to demonstrate that we are not going to be overrun by 'blacks'." (Principal, Weka College).

This example raises important issues about the relationship between school mix and student achievement. Given that there is a close relationship between ethnicity and school achievement, moving to a school with a relatively high percentage of Pakeha students may be a strategy which is likely to improve achievement for some students. However, if the popularity of a school is largely determined by the number of Pakeha students who attend it, then it is not in the interests of the school to accept large numbers of non-Pakeha students. The schools in the sample with the highest percentage of Pakeha students were able to operate enrolment schemes, and so control their ethnic mix. However, the case study school described above was not able to operate an enrolment scheme, and thus had to take "all comers". The effect of this white flight out of Weka College and brown flight in has been to dramatically alter the ethnic and SES composition of the school, and has the ironic consequence of threatening any advantage the school may have been able to offer via the "school mix" effect. Furthermore, the effect of brown flight into this school has been devastating on the schools which traditionally provided for these students. When the relatively advantaged Pacific Island and Maori students left, the SES mix of one of the schools adjacent to Weka College dropped from 5.1 in 1989 to 5.9 in 1995 .

\section{Reflection}

At this point it is worth stepping back and thinking over what this movement between schools is about. Presumably it is based on the assumption that some schools are better than others or, if they are not actually better, that they differ in significant ways. If it is the case that there is a real difference in quality of educational provision, over and above that which is determined by the school mix effect which most schools have little control over, then there is a strong case to be made for facilitating movement of students between schools. If however, there is very little diversity in terms of quality or type, then we have to ask what it is that parents and students are actually choosing when they choose a school. We also have to ask what the overall social effects are of a policy that facilities the movement of relatively advantaged students, and which enables those schools with the highest percentage of Pakeha middle-class students to exercise exclusion. If these are the "best" schools, we must ask why they are best and for whom they are best.

Research by Harker and Nash (1996) in the Progress at School study provides quantitative data examining the ability of schools to achieve certain academic outcomes. "In all three subjects [mathematics, science and English] about two-thirds of the between-school variance can be accounted for by the characteristics of the students in attendance" (p. 158). In other words, the schools which appear most successful in gross measures of productivity are successful because of their relatively high SES mix, rather than educational processes per se. Where individual students from low SES backgrounds attend such schools, Harker and Nash suggest that their performance may be improved. However, they also consider what effect the 37 schools in their study 
were able to have on student academic achievement, once the student mix of the school was controlled for. They found that only one-third of the between-school variance could be explained by the effects of withinschool processes such as pedagogy and curriculum. However, some schools which scored poorly in terms of gross productivity were very successful in promoting academic achievement. For example, one of the schools in their study had a high percentage of students from low SES backgrounds and scored poorly on gross achievement measures. However, once the student mix of the school was controlled for, Harker and Nash show that "the school is doing a better job than many schools with a much more 'favourable' pupil mix" (p. 160).

Harker and Nash conclude by recommending that equalising the SES mix of school intakes would contribute to equalising academic outcomes. Because SES is so closely linked to ethnicity, we also need to consider the implications of movements between schools for Maori and Pacific Islands students. The emotive and catchy phrase "white and brown flight" is in danger of obscuring more important issues relating to ethnicity and school provision. The implication that large numbers of relatively-advantaged Maori and Pacific Islands students are moving away from schools with high proportions of these students, to schools with higher proportions of Pakeha students, may imply that schools with high proportions of Pakeha students are best able to meet the needs of Maori and Pacific Islands students. Many decades of research and experience by Maori have clearly shown that this is not the case. While it may be true that some Maori students may have their achievement promoted by attending schools with a high SES mix, this is not so for most. The mainstream state schooling system in Aotearoa/New Zealand has been shown to be deeply racist, and even where Maori do achieve, it has been in a system in which they are marginalised and devalued.

As Smith (1991) has argued, the consistent failure of the education system to meet the needs of Maori was the reason for the development of Kohanga Reo and Kaupapa Maori. It is important to note that it was not competition and individual choice which created these initiatives, but cooperative, collective whanau-and iwi-based political action. "Kura Kaupapa Māori are proactive educational responses which Māori parents have been forced to take themselves, given the inability (perhaps reluctance) of the dominant Pākehā educational structures to successfully intercede in Māori underachievement, and in the ongoing assimilation of Māori culture and language" (p. 32). In a similar way, our research is beginning to show that schools which have been hardest hit by the impact of marketisation are those which are working in creative, cooperative ways to address the needs of the Maori and Pacific Islands communities they serve. The tragedy is that these schools are the most poorly resourced. We know of one Decile 1 school $^{1}$ which raised just $\$ 300$ in private funding in total in the last financial year, in contrast to a Decile 10 school which charges the same amount in school fees for every student, and which raises thousands more in fundraising. The equity funding provided by the state to the Decile 1 school in no way matches this amount. Because of the relationship between ethnicity, socioeconomic status and school achievement, it is easy to see who will be judged the "better" school in the achievement stakes.

It is our view that the (limited) diversity of provision that exists in the schooling system has not been generated by the competition that choice policies aimed to promote. Indeed it may militate against it. On the one hand, schools with a high SES mix do not have to compete for students and are able to exercise a high degree of control over their intakes. On the other hand, schools which serve communities with large numbers of Maori and Pacific Islands students have been hardest hit by competition. They are not in the business of competing for students; they have the task of working with, and for, those students who are not able to compete in the education market place. From this perspective, the ethnic polarisation of school intakes might be seen to be advantageous if it meant that state schools were able to develop policies and practices within which Maori could feel "culturally safe", with a resulting sense of increased educational self-esteem and better educational results. In the United States, Coleman (1990) has also supported this position, arguing that "all-black" schools should not automatically be seen as a problem:

Recognition that all-black schools are not inherently inferior has important implications. Perhaps the most significant is the realisation that the ethically and culturally pluralistic society of the United States has room for schools of all sorts. What is essential... is that if a child is in an all-black school it is because he [sic] wants to be there and his parents want him to be there, not because it is the only school he has reasonable chance to attend. (p. 216)

We would add that if true diversity is to exist, not just diversity in achievement as an outcome of school mix, then schools in Maori and Pacific Islands communities need to be abundantly resourced in order 
to develop and provide innovative educational programmes. One of the schools in our study has been developing a bicultural context and has been quite successful in attracting Maori students. But at the same time, the number of third form entrants has dropped steadily throughout the six years recorded, and there is a notable decline in the proportion of girls in the form three intake. Recruitment of Pakeha students fluctuated during this period, while the percentage of Pacific Islands students attending declined. In essence, the strategy of seeking to develop a school with a strong emphasis on Maori values and practices was undertaken while the school roll was in a spiral of decline, and while the school was having to attend to issues related to fluctuation in an ethnically diverse population, quite apart from the planned increase in Maori students.

While there has been consistent demand from Maori for a bicultural education system (and a legal obligation according to the Treaty of Waitangi to do so) the needs of Pacific Islands communities have not been so easily defined. In one of our case study schools, which has an intake of almost 100 percent Pacific Islands students, the principal describes the mandate they have been given from the community in this way:

The parents want their children to succeed in educational terms, in Pakeha terms. They want their kids to be "normal". They want the passport, just like the kids want - the students want the passport.

The second thing is that they are not quite so interested in being culturally enriched, because they feel that they can do that in their own communities. So they are not terribly impressed with the fact that we try to reflect the Pacific Islands and Maori cultures in some of the activities we do here, because they feel they can take care of the cultural enrichment and development in their own lives.

Our research has shown that the issues relating to ethnicity and school choice are complex and dynamic. Our considerable involvement with schools and the Smithfield cohort families leaves us convinced that there are few so-called "disadvantaged" students and schools which have benefited from the major changes to secondary school zoning policies. It is our belief, as we have consistently recommended in our research reports, that all students should have the right to attend their local school and that state resources should be allocated to ensure that every school in New Zealand provides a quality education for the students who attend it, regardless of their ethnicity, gender or socio-economic background. We would go further to argue that if, as a society, we want to overcome the poverty and disadvantage that is the daily reality for many students, and if we believe that education can have some part to play in breaking the cycle of poverty and disadvantage, then schools which serve these students should be abundantly resourced to do so. It is our belief that competition has not brought about, and will not bring about, social justice. In many cases, it has only served to increase educational, and ultimately social, inequalities.

These may seem strong claims, but they are no stronger than the opposing claims made by proponents of marketisation. We, like many principals, teaching staff, parents and students with whom we have worked, remain very concerned about the ways in which market policies are impacting on the quality and efficacy of educational provision in Aotearoa/New Zealand.

In conclusion we would like to acknowledge the Ministry of Education for funding this research, previous members of the Smithfield Project team, and the families and schools who have given so generously of their time to provide us with information.

Note

1. In 1995 the Ministry of Education introduced a socio-economic indicator for schools derived from Census data on a random sample of each school's roll. Schools are given a Decile ranking from 1-10. Decile 1 schools are those deemed to have the greatest socio- economic need. The Ministry uses this indicator as a means of targeting schools for additional funding, primarily Targeted Funding For Educational Achievement (TFEA), also known as equity funding.

\section{References}

Ball, S., Bowe, R., \& Gewirtz, S. (1995). Circuits of schooling: A sociological exploration of parental choice in social class contexts. Sociological Review, 43, 52-78.

Benton, R. (1987). How fair is New Zealand education? Part 2: Fairness in Maori education. Wellington: New Zealand Council for Educational Research.

Brown, P. (1987). Schooling ordinary kids. London: Tavistock.

Chapman, J. (1995). Parental choice in school education. Public Sector, $16(2), 8-11$. 
Coleman, J. (1990). Equality and achievement in education. Boulder: Westview Press.

Gordon, L. (1994). Is school choice a sustainable policy for New Zealand?: A review of recent research findings and a look to the future. New Zealand Annual Review of Education, 4, 9-24.

Harker, R \& Nash, R. (1996). Academic outcomes and school effectiveness: Type "A" and type "B" effects. New Zealand Journal of Educational Studies, 32(2), 143-170.

Lauder, H., Hughes, D., Dupuis, A., \& McGlinn, J. (1992). To be somebody: Class, gender and the rationality of educational decision-making. Wellington: Ministry of Education.

Lauder, H., Hughes, D., Waslander, S., Thrupp, M., McGlinn, J., Newton, S. \& Dupuis, A. (1994). The creation of market competition for education in New Zealand. First report to the Ministry of Education. Wellington: Victoria University of Wellington.

Lauder, H., Hughes, D., Watson, S., Simiyu, I., Strathdee, R. \& Waslander, S. (1995). Trading in futures: The nature of choice in educational markets in New Zealand. Third report to the Ministry of Education. Wellington: Victoria University of Wellington.

Maddaus, J. (1990). Parental choice of school: What parents think and do. In C. Cazden (Ed.), Review of Research in Education, 16, pp. 267-296.

McCulloch, G. (1990). Secondary school zoning: The case of Auckland. In J. Codd, R. Harker, \& R. Nash (Eds.), New Zealand education policy today: Critical perspectives. Second Edition (pp. 238-302). Palmerston North: Dunmore Press,

McCulloch, G. (1991). School zoning, equity and freedom: The case of New Zealand. Journal of Education Policy, 6(2), 155-168.

Smith, G. (1991). Tomorrow's Schools and the development of Maori education. (Monograph No. 5). Auckland: University of Auckland.

Smith, G. (1995). Whakaoho whanau. He Pukenga Korero. Palmerston North: Massey University.

Wells, A. (1995). African-American student's views of school choice. In B. Fuller, R. Elmore, \& G. Orfield (Eds.), School choice: The cultural logic of families, the political rationality of schools. New York: Teachers College Press.

\section{The authors}

The authors are members of the Smithfield Project team, established by the Directors Hugh Lauder and David Hughes in 1992 and funded by the Ministry of Education. Hugh Lauder was previously Professor of Education at Victoria University of Wellington and is now Chair of Education at the University of Bath, in England. David Hughes is a senior lecturer in education at Canterbury University. Sue Watson is a $\mathrm{PhD}$ student in education at Victoria University and Robert Strathdee is a PhD student in education at Canterbury University. Ibrahim Simiyu is a research consultant now based in Auckland. 